\title{
Eicosapentaenoic Acid Productivity of the Bacteria Isolated from Fish Intestines
}

\author{
Kazunaga Yazawa, ${ }^{* 1}$ Keiko Araki,*1 Kazuo Watanabe,*1 \\ Chikako Ishikawa, ${ }^{* 1}$ Akira Inoue, ${ }^{* 1}$ Kiyosi Kondo, ${ }^{* 1}$ \\ Shugo Watabe,*2 and Kanehisa Hashimoto*2 \\ (Received April 4, 1988)
}

\begin{abstract}
Attempts were made to find eicosapentaenoic acid(EPA)-producing microorganisms. Out of some 7,000 bacterial strains screened, 112 of them showed more or less this activity. Most of them were isolated from intestinal contents of marine fishes which were known to contain high levels of EPA in their body lipid. A bacterial strain isolated from the Pacific mackerel Pneumatophorus japonicus showed a high productivity of EPA $(3.8$ to $10.8 \mathrm{mg} / \mathrm{g}$ dry cells) and also a high ratio of EPA to total fatty acids ( 27.8 to $36.3 \%$ ). The strain was Gram-negative, motile, obligate aerobic and short rod-shaped, which we judge it to be a new species close to genus Alteromonas.
\end{abstract}

The epidemiological investigation on Greenland Eskimos by Dyerberg and co-workers ${ }^{1,2)}$ demonstrated that EPA is effective for prevention and cure of thrombosis, arteriosclerosis and subsequent blood-circulatory diseases. In other words, EPA is allegedly important for us to maintain homeostasis. ${ }^{1,3-6)}$ Some marine fishes also require EPA as essential, and usually contain this fatty acid at a fairly high level. $\left..^{7}, 8\right)$

It is gerenrally accepted that EPA in fish comes from marine algae and phytoplankton via the food chain..$^{\text {g) }}$ Recently, Wirsen et al. ${ }^{10)}$ have claimed that a psychrophilic and barophilic marine bacterium collected from the deep sea contained " $a \mathrm{C}_{20: 5}$ polyunsaturated fatty acid" of unknown structure. Many organisms, such as bacteria, fungi, plants, and even animals are known to maintain the optimal fluidity and function as the environmental temperature or pressure varies, by altering proportions of unsaturated fatty acids. ${ }^{11,12)}$ This situation prompted us to search for EPA elaborators from marine microorganisms inhabiting fish intestines and other environments. We have already isolated some EPA-producing bacteria and reported the data elsewhere. ${ }^{133}$ Further screening for EPA-producers was performed and this report deals with the results obtained, along with identification of a bacterium which showed a notable productivity of EPA.

\section{Materials and Methods}

Some 7,000 strains of marine microorganisms were isolated from various marine sources such as intestinal contents of fish and shellfish, zooplankton, seawater and sediment (Table 1). Bacterial clolonies were picked up from such samples by the usual method using the following media; GAM "Nissui", Nutrient agar "Nissui", Salt polymyxin "Nissui", TCBS agar "Eiken", BTB Teepol agar "Nissui", Mannitol salt agar "Eiken", NAC agar "Eiken", Potato dextrose agar "Nissui", Sabouraud agar "Nissui", Czapek Dox agar "Nissui", Bacto-Marine agar 2216, Malt agar "Nissui", and Trypto-Soy agar "Eiken". Each strain was cultured at $25^{\circ} \mathrm{C}$ for 2 days in "P-Y-MGlucose medium" which contained $1 \%$ peptone, $0.5 \%$ yeast extract, $0.25 \%$ meat extract and $2 \%$ glucose in $1 / 2$ concentration of an artificial seawater ("Jamarin S", Jamarin laboratory, Osaka). Cells were havrested by centrifugation and extracted with chloroform-methanol $(2: 1, \mathrm{v} / \mathrm{v})$. The extract was evaporated to eliminate the organic solvents. The resulting lipid was saponified by the usual method, and analyzed for fatty acids by gas liquid chromatography (GLC) after methylation with diazomethane. Sterols and other non-saponifiable matters were checked by thinlayer chromatography (TLC) using; n-hexane: ethyl ether: formic acid (80: 20:0.2, v/v) as

*1 Sagami Chemical Research Center, Nishi-Ohnuma, Sagamihara, Kanagawa 229, Japan (矢澤一良, 荒 木恵子, 渡部和郎, 石川干夏子, 井上玲, 近藤 聖：相模中央化学研究所).

*2 Laboratory of Marine Biochemistry, Faculty of Agriculture, University of Tokyo, Bunkyo, Tokyo 113, Japan (渡部終五, 橋本周久: 東京大学農学部). 
Table 1. Details of the fish and other samples used

\begin{tabular}{ll}
\hline \hline & \multicolumn{1}{c}{ Place and date of collection } \\
\hline Fishes: & \\
Pacific mackerel Pneumatophorus japonicus & Saganoseki, Oita Pref,, Feb. 1987 \\
Horse mackerel Trachurus japonicus & Ajiro, Kanagawa Pref., Sept. 1986 \\
Sardine Sardinops melanosticta & Onahama, Fukushima Pref., April 1987 \\
Flying fish Cypselurus heterurus doderleini & Masuda, Shimane Pref., July 1987 \\
Saury-pike Cololabis saira & Hokkawa, Shizuoka Pref,, May 1987 \\
Yellowtail Seriola quinqueradiata & Masuda, Shimane Pref., July 1987 \\
Anchovy Engraulis japonica & Kamakura, Kanagawa Pref., Nov. 1986 \\
Pike Sphyraena pinquis & Masuda, Shimane Pref., July 1987 \\
Alaska pollack Theragra chalcogramma & Yoichi, Hokkaido, Jan. 1987 \\
Chum salmon Oncorhynchus keta & Sanriku, Iwate Pref., Dec. 1986 \\
Invertebrates: & \\
Squid Doryteuthis bleekeri & Hokkawa, Shizuoka Pref., May 1987 \\
Krill Euphausiacea & Onahama, Fukushima Pref., April 1987 \\
Seawater & Nagai, Kanagawa Pref., Oct. 1986 \\
Sediment & Nagai, Kanagawa Pref., Oct. 1986 \\
\hline
\end{tabular}

solvent.

Transmittance electron microscopy was performed on a TEM-100CX (JEOL, negative stain) by the usual method. Biological and biochemical characters of a bacterium were examined according to the Bergey's mannual. ${ }^{14}$ )

\section{Results and Discussion}

Results showed that 112 out of some 7,391 strains tested produced EPA. One hundred and four strains of them were isolated from intestinal contents of marine fishes such as Pacific mackerel, horse mackerel, sardine, flying fish and saurypike, all of which usually contain EPA at a high level. On the contrary, few EPA-producing microorganisms were isolated from other organisms, seawater, etc. (Table 2). This fact suggests that the said fishes directly utilize EPA produced by those bacteria, in addition to EPA supplied by the food chain.

One of the EPA elaborators isolated from Pacific mackerel exhibited a remarkably high ability when cultured in P-Y-M-Glucose medium at $25^{\circ} \mathrm{C}$ for $18 \mathrm{~h}$. This strain, tentatively named SCRC-2738, was Gram-negative, rod-shaped, motile by means of peritrichous flagella, and essentially required a natural or artificial seawater and oxygen for growth.

SCRC-2738 strain which was $0.5-1.5 \mu \mathrm{m}$ diameter and 1.5-2.5 $\mu \mathrm{m}$ length (Fig. 1), was examined for 60 items of various biological and biochemical characters. Over 50 out of 60 items of characters of our strain were the same as those
Table 2. Detection of EPA-producing bacteria in marine fishes

\begin{tabular}{lcc}
\hline \multicolumn{3}{c}{$\begin{array}{c}\text { EPA-producing } \\
\text { strains }\end{array}$ Strains } \\
tested \\
\hline Pacific mackerel & $40(8)^{* 1} / 1403$ & $(2.9 \%)^{* 2}$ \\
Horse mackerel & $36(1) / 1346$ & $(2.6 \%)$ \\
Sardine & $11(4) / 748$ & $(1.5 \%)$ \\
Flying fish & $12(3) / 650$ & $(1.8 \%)$ \\
Saury-pike & $5(2) / 295$ & $(1.7 \%)$ \\
Yellowtail & $4(0) / 328$ & $(1.2 \%)$ \\
Anchovy & $2(2) / 360$ & $(0.6 \%)$ \\
Pike & $1(0) / 333$ & $(0.3 \%)$ \\
Alaska pollack & $1(0) / 424$ & $(0.2 \%)$ \\
Chum salmon & $0 / 280$ & \\
Squid & $0 / 536$ & \\
Krill & $0 / 268$ & \\
Seawater & $0 / 196$ \\
Sediment & $0 / 224$ \\
\multicolumn{4}{c}{ *1 Highly producing strains $(>10 \mathrm{mg} / l)}$. \\
*2 Frequency of EPA-producing strains.
\end{tabular}

of Alteromonas putrefaciens. As shown in Table 3, the strain was generally similar to Alt. putrefaciens ${ }^{14,15)}$ except for several important characters such as ornithine decarboxylase activity, citrate utilization, seawater requirement, and growth at $37^{\circ} \mathrm{C}$.

In addition, both bacteria distinctly differed from each other in respect of flagellation: Our strain was peritrichous, whereas the cited and any other Alteromonas strains so far reported not. On the other hand, genous Alcaligenes has peritrichous flagella. However, genous Alcaligenes and SCRC-2738 distinctly differed from 


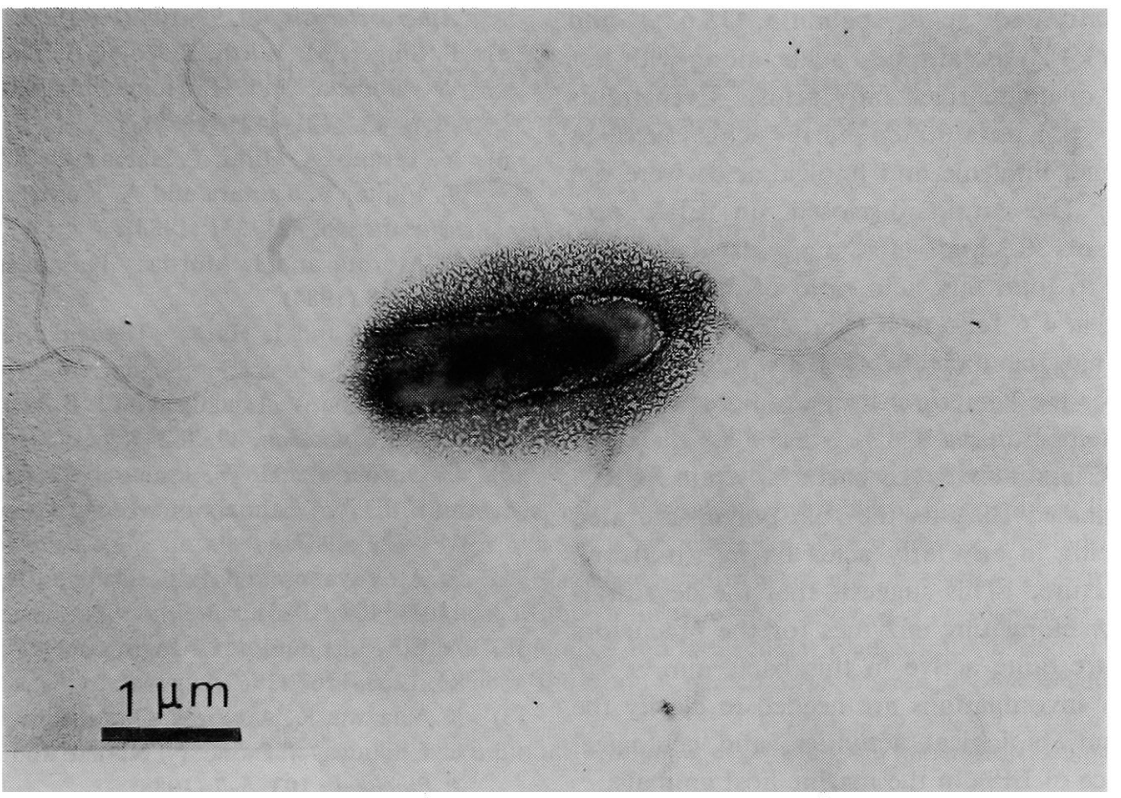

Fig. 1. Electron micrograph of a new EPA-producing bacterium SCRC-2738.

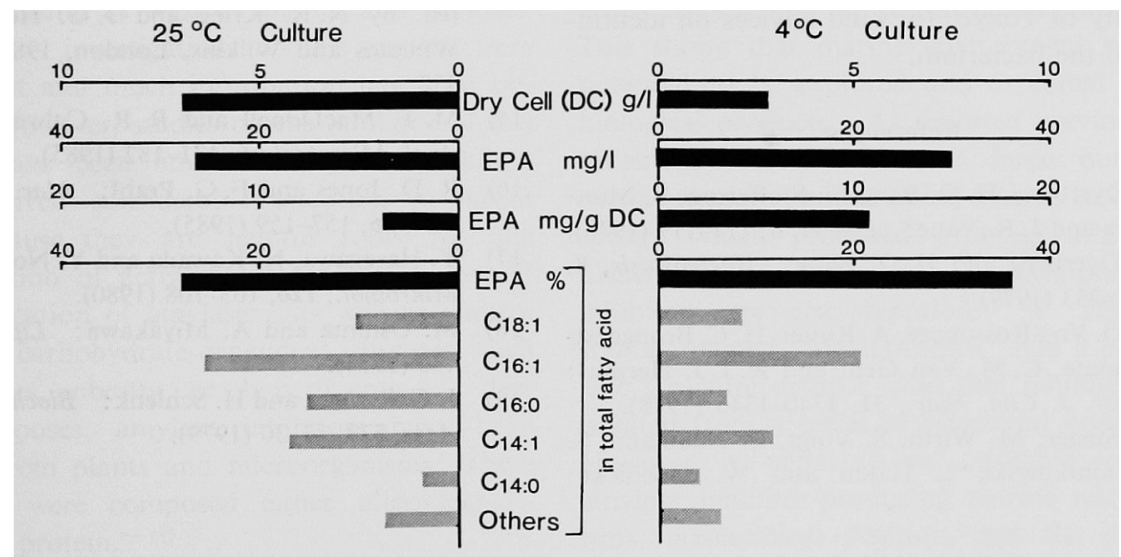

Fig. 2. EPA-production and fatty acid composition of the bacterium SCRC-2738 which was cultivated at $25^{\circ} \mathrm{C}$ for $18 \mathrm{~h}$ or $4^{\circ} \mathrm{C}$ for 5 days.

each other in respect of $\mathrm{G}+\mathrm{C}$ contents of DNA (Alcaligenes had $56-70 \%$, whereas SCRC-2738 had $45.0 \%$ ), and other important characters such as gelatin hydrolysis, DNase and growth at $37^{\circ} \mathrm{C}$. The facts that SCRC-2738 required seawater and did not grow at $37^{\circ} \mathrm{C}$, along with the fact that it contained no sterols in the cell as demonstrated by TLC (data not shown), indicate that our strain SCRC-2738 was a marine bacterium. Based on these results, we have concluded that SCRC2738 strain is similar to, but not identical with, genus Alteromonas. The strain showed the optimum growth when cultured at the initial
pH 7.0 and at $25^{\circ} \mathrm{C}$ for $18 \mathrm{~h}$ aerobically, resulting a yield of $7 \mathrm{~g}$ dry cells $/ l$ medium, or $2 \times 10^{10}$ viable cells $/ \mathrm{ml}$. It showed a doubling time of $30 \mathrm{~min}$ on the exponential phase. The amount of EPA produced increased in parallel with cell growth, reaching a maximum of $26.1 \mathrm{mg} / \mathrm{l}$ or $3.8 \mathrm{mg} / \mathrm{g}$ dry cells, on the late exponential phase. The strain did not grow at all at $\mathrm{pH} 5$ or 10 , and at $37^{\circ} \mathrm{C}$.

GLC demonstrated that this bacterium exclusively possessed EPA $(27.8 \%)$ as a polyunsaturated acid, in addition to oleic $(10.2 \%)$, palmitoleic $(25.9 \%)$ and myristoleic $(17.1 \%)$ as 
monounsaturated acids, palmitic $(15.6 \%)$ and myristic $(3.4 \%)$ as saturated acids, along with less than $5 \%$ of unidentified fatty acids. Even traces of other polyunsaturated fatty acids such as arachidonic, linolenic and linoleic acids were not detected. The strain disclosed an EPA productivity of $30.3 \mathrm{mg} / /(10.8 \mathrm{mg} / \mathrm{g}$ dry cells $)$ and the EPA to total faty acid ratio of $36.3 \%$, when cultivated at $4{ }^{\circ} \mathrm{C}$ for 5 days (Fig. 2). These results suggest that the increase of EPA might be important for the bacterium to maintain cell fluidity at lower temperatures..$^{18-19)}$

As described above, the bacterial strain SCRC2738 contained EPA as the sole polyunsaturated acid, lacking in any fatty acids having ( $\mathrm{n}-3)$ and (n-6) structure. This suggests that the desaturating and/or elongating enzymes for the precursors of EPA are quite active in this bacterium. ${ }^{19}$ )

Further investigations are needed to clarify the metabolism, biological activities, and ecological significance of EPA in the marine host animals.

We are indebted to Dr. K. Yamasato and Miss M. Akagawa, Institute of Applied Microbiology, University of Tokyo, for kind advices on identification of the bacterium.

\section{References}

1) J. Dyerberg, H. O. Bang, E. Stofferson, S. Moncada and J. R. Vane: Lancet, ii, 117-119 (1978).

2) J. Dyerberg and H. O. Bang: Haemostasis, 8 , 227-233 (1979).

3) T. O. Von Rossonczy, A. Ruiter, H. C. BrongeestSchoute, C. M. Van Gent and R. J. J. Hermus: Amer. J. Clin. Nutr, 31, 1340-1346 (1978).

4) P. Singer, M. Wirth, S. Voigt, E. Naumann, S. Zimontkowski, I. Hajdu and W. Goedicke:
Atherosclerosis, 49, 99-108 (1983).

5) P. Singer, M. Wirth, S. Voigt, S. Zimontkowski, W. Godicke and H. Heine: Biomed. Biochim. Acta, 43, s421-5425 (1984).

6) Y. Terano, A. Hirai, T. Hamazaki, S. Kobayashi, T. Fujita, Y. Tamura and A. Kumagai: Atherosclerosis, 46, 321-331 (1983).

7) S. Murota and 1. Morita: Igakunoayumi, 130, 787-798 (1984).

8) Y. Ohno and I. Hara: Yukagaku, 30, 784-790 (1981).

9) M. Kayama, Y. Tsuchiya and J. F. Mead: Nippon Suisan Gakkaishi, 29, 452-458 (1963).

10) C. O. Wirsen, H. W. Jannasch. S. G. Wakeham and E. A. Cannel: Current Microbiol,, 14, 319-322 (1987).

11) A. A. Yayanos and E. F. Deloy: Science, 228, 1101-1102 (1985).

12) A. G. Marr and J. L. Ingraham: J. Bacteriol., 84, 1260-1267 (1962).

13) K. Yazawa, K. Araki, N. Okazaki, K. Watanabe, C. Ishikawa, A. Inoue, N. Numao and K. Kondo: J. Biochem., 103, 5-7 (1988).

14) P. Baumann, M. J. Gauther, and L. Baumann: in "Bergey's Manual of Systematic Bacteriology" (ed. by N. R. Krieg and J. G. Holt) Vol. 1, Williams and Wilkins, London, 1984, pp. 343352 ,

15) M. T. MacDonell and R. R. Colwell: System. Appl. Microbiol., 6, 171-182 (1985).

16) R. D. Jones and F. G. Prahl: Mar. Ecol. Prog. Ser., 26, 157-159 (1985).

17) Y. Hasegawa, N. Kawada and Y. Nosoh: Arch. Mikrobiol., 126, 103-108 (1980).

18) M. Oshima and A. Miyakawa: Lipids, 9, 476480 (1974).

19) J. Gellerman and H. Schlenk: Biochim. Biophys. Acta, 573, 23-30 (1979). 